\title{
PEMBERIAN JUS APEL HIJAU TERHADAP PENURUNAN KADAR KOLESTEROL PADA PASIEN HIPERKOLESTEROLEMIA DI KOTA METRO
}

\author{
DOI: https://doi.org/10.33024/jkpm.v4i5.2829 \\ Meilisa Tabrani ${ }^{1}$, Djunizar Djamaludin ${ }^{2 *}$ \\ ${ }^{1}$ Mahasiswa Program Studi Ilmu Keperawatan Universitas Malahayati \\ ${ }^{2}$ Dosen Program Studi Ilmu Keperawatan Universitas Malahayati \\ Disubmit: 30 Juni 2020 Diterima: 03 Mei 2021 Diterbitkan: 03 Oktober 2021 \\ Email Korespondensi: bluenavi01@gmail.com
}

\begin{abstract}
ABSTRAK
Pada penduduk $>15$ tahun didapatkan kolesterol total abnormal 35,9\% ( $\geq 200$ $\mathrm{mg} / \mathrm{dl}$ ), HDL rendah 22,9\% yang kurang dari $40 \mathrm{mg} / \mathrm{dl}$, LDL tidak optimal dengan kategori gabungan near optimal dan borderline tinggi 60,3\% serta kategori tinggi dan sangat tinggi 15,9\% ( $\geq 190 \mathrm{mg} / \mathrm{dl})$, trigliserida abnormal kategori borderline tinggi $13,0 \%$ serta kategori tinggi dan sangat tinggi $11,9 \%$ ( $\geq 500 \mathrm{mg} / \mathrm{dl}$ ). Kolesterol adalah suatu zat berlemak yang diperlukan di dalam tubuh manusia untuk sintesa berbagai steroida. Cara mengatasi kelebihan kolesterol dalam darah dengan farmakologi dan nonfarmakologi. Cara nonfarmakologi menurunkan kadar kolesterol dengan mengonsumsi jus apel hijau. Tujuan untuk mendapatkan pengalaman yang nyata dan kompetensi lebih dalam pemberian asuhan keperawatan komprehensif pemberian jus apel hijau terhadap penurunan kadar kolesterol. Adapun intervensi yang dilakukan dengan pemberian jus apel hijau sebanyak $200 \mathrm{ml}$ selama 7 hari, diminum rutin satu kali sehari sesudah makan berbuka puasa. Terdapat penurunan kadar kolesterol setelah diberikan jus apel hijau pada klien kolesterol. Dengan demikian, pemberian jus apel hijau efektif dapat menurunkan kadar kolesterol.
\end{abstract}

Kata Kunci: Kolesterol, Jus Apel Hijau

\begin{abstract}
In the population of $>15$ years are obtained abnormal total cholesterol $35,9 \%$ ( $\geq 200 \mathrm{mg} / \mathrm{dl}$ ), low HDL $22,9 \%$ which is less than $40 \mathrm{mg} / \mathrm{dl}, \mathrm{LDL}$ is not optimal with the category of combined near-optimal and high borderline 60,3\% as high category and very high $15,9 \%(\geq 190 \mathrm{mg} / \mathrm{dl}$ ), abnormal triglycerides category high borderline $13,0 \%$ as high category and very high $11,9 \%(\geq 500 \mathrm{mg} / \mathrm{dl}$ ). Cholesterol is a fatty substance in the human body for the synthesis of various steroids. The method to reduce hyper cholesterol in the blood can by pharmacological and non-pharmacological. The nonpharmacological method was consuming green apple juice. The purpose was to get real experience and more competence in providing comprehensive nursing care. The intervention was given green apple juice as much as $200 \mathrm{ml}$ for 7 days, taken routinely once a day after iftar. There was cholesterol levels reduction of cholesterol client after gave green apple juice. Thus, green apple juice effectively reduces cholesterol levels.
\end{abstract}

Keywords: Cholesterol, Green Apple Juice 
Tahun [JURNAL KREATIVITAS PENGABDIAN KEPADA MASYARAKAT (PKM), P-ISSN:

2021 2615-0921 E-ISSN: 2622-6030 VOLUME 4 NOMOR 5 OKTOBER 2021] HAL 1176-1183

\section{PENDAHULUAN}

Bersumber pada data dari WHO MONICA I (Monitoring Trends and Determinants in Cardiovascular Diseases), persentase prevalensi hiperkolesterolemia pada perempuan yaitu sebesar $13,4 \%$ dan pada laki-laki yaitu sebesar $11,4 \%$. Data dari MONICA II diperoleh mengalami peningkatan pada perempuan menjadi sebesar $16,2 \%$ dan pada laki-laki menjadi sebesar $14 \%$. Hal ini menunjukkan bahwa kelompok paling banyak yang menderita masalah ini yaitu perempuan (Naue, Doda, \& Wungouw, 2016).

Berdasarkan data di Indonesia dari Riset Kesehatan Dasar Nasional (RISKEDAS) tahun 2013 menunjukkan bahwa pada penduduk >15 tahun didapatkan kolesterol total abnormal 35,9\% (berdasarkan NCEP ATP III, dengan kadar kolesterol $\geq 200 \mathrm{mg} / \mathrm{dl}$ ) dimana perempuan lebih banyak daripada laki-laki dan perkotaan lebih banyak daripada di pedesaan (Perkumpulan Endokrinologi Indonesia, 2015). Prevalensi peningkatan kolesterol total (>200 mg/dl) yaitu 40\% pada perempuan dan 30\% pada laki-laki di Indonesia (Lestiani, et al., 2018). Prevalensi kolesterol yaitu 66,41\% di Indonesia. Kolesterol yang ditemukan lebih dari 50\% pada 18 dari 20 provinsi di Indonesia dan 23 dari 27 kelompok etnis (Herningtyas, \& Ng, 2019). Pada populasi Indonesia, perempuan memiliki prevalensi kolesterol yang lebih tinggi dibandingkan laki-laki yaitu sebesar 45,3\% pada perempuan dan 28,6\% pada laki-laki (Sigit, et al., 2020).

Kolesterol adalah suatu zat berlemak yang diperlukan di dalam tubuh manusia untuk sintesa berbagai steroida serta pembentukan jaringan otak dan sel syaraf. Tubuh dapat membuat kolesterol sendiri dari biosintesa asetat dalam limpa dan disebut kolesterol endogen. Selain itu, tubuh memperoleh kolesterol dari dua sumber yaitu dari makanan yang disebut kolesterol eksogen (Moehji, 2017).

Adapun cara penanganan untuk mengatasi kelebihan kolesterol dalam darah bisa dilakukan dengan cara farmakologi dan nonfarmakologi. Salah satu cara nonfarmakologi menurunkan kadar kolesterol dalam darah dengan mengonsumsi jus apel hijau. Apel hijau sebagai solusi selain obat yang dapat dimanfaatkan untuk menurunkan kadar kolesterol berlebih pada tubuh dikarenakan kandungan pektin yang dikenal sebagai antikolesterol karena dapat mengikat asam empedu yang merupakan hasil akhir metabolisme kolesterol, makin banyak asam empedu yang berikatan dengan pektin dan terbuang keseluruh tubuh makin banyak kolesterol yang di metabolisme, sehingga pada akhirnya kolesterol menurun jumlahnya. Apel juga memiliki flavonoid yang merupakan antioksidan potensial pencegah pembentukan radikal bebas. Senyawa ini mampu mencegah perlengketan sel darah dan kerusakan HDL. Asupan makanan sumber flavonoid mengencerkan kembali darah pekat akibat penyumbatan pembuluh darah oleh kolesterol dan menjaga kadar normal HDL (Darsini, 2017).

Berdasarkan latar belakang ini, maka peneliti tertarik untuk menyusun laporan keperawatan komprehensif dengan judul Asuhan Keperawatan Komprehensif Pemberian Jus Apel Hijau Terhadap Penurunan Kadar Kolesterol pada Klien Kolesterol di Kota Metro. 
Tahun [JURNAL KREATIVITAS PENGABDIAN KEPADA MASYARAKAT (PKM), P-ISSN:

2021 2615-0921 E-ISSN: 2622-6030 VOLUME 4 NOMOR 5 OKTOBER 2021] HAL 1176-1183

\section{MASALAH}

Alasan saya memilih tempat intervensi dan demontrasi pemberian jus apel hijau terhadap penurunan kadar kolesterol di Kota Metro karena keluarga saya memiliki masalah kesehatan kolesterol tinggi, dimana tujuan umum diharapkan mendapatkan pengalaman yang nyata dan kompetensi lebih dalam pemberian asuhan keperawatan komprehensif pemberian jus apel hijau terhadap penurunan kadar kolesterol pada klien kolesterol. Tujuan khusus dalam kegiatan yaitu telah dilaksanakan pengkajian asuhan keperawatan komprehensif pemberian jus apel hijau, telah dilaksanakan analisis jurnal dan mengidentifikasi diagnosa keperawatan untuk menentukan salah satu intervensi yang akan diberikan sesuai masalah keperawatan yang muncul, telah dilaksanakan intervensi keperawatan pemberian jus apel hijau sesuai dengan hasil telaah jurnal, telah dilaksanakan implementasi keperawatan, dan telah dilaksanakan evaluasi membandingkan hasil implementasi keperawatan pemberian jus apel hijau pada klien kolesterol sesuai dengan jurnal.

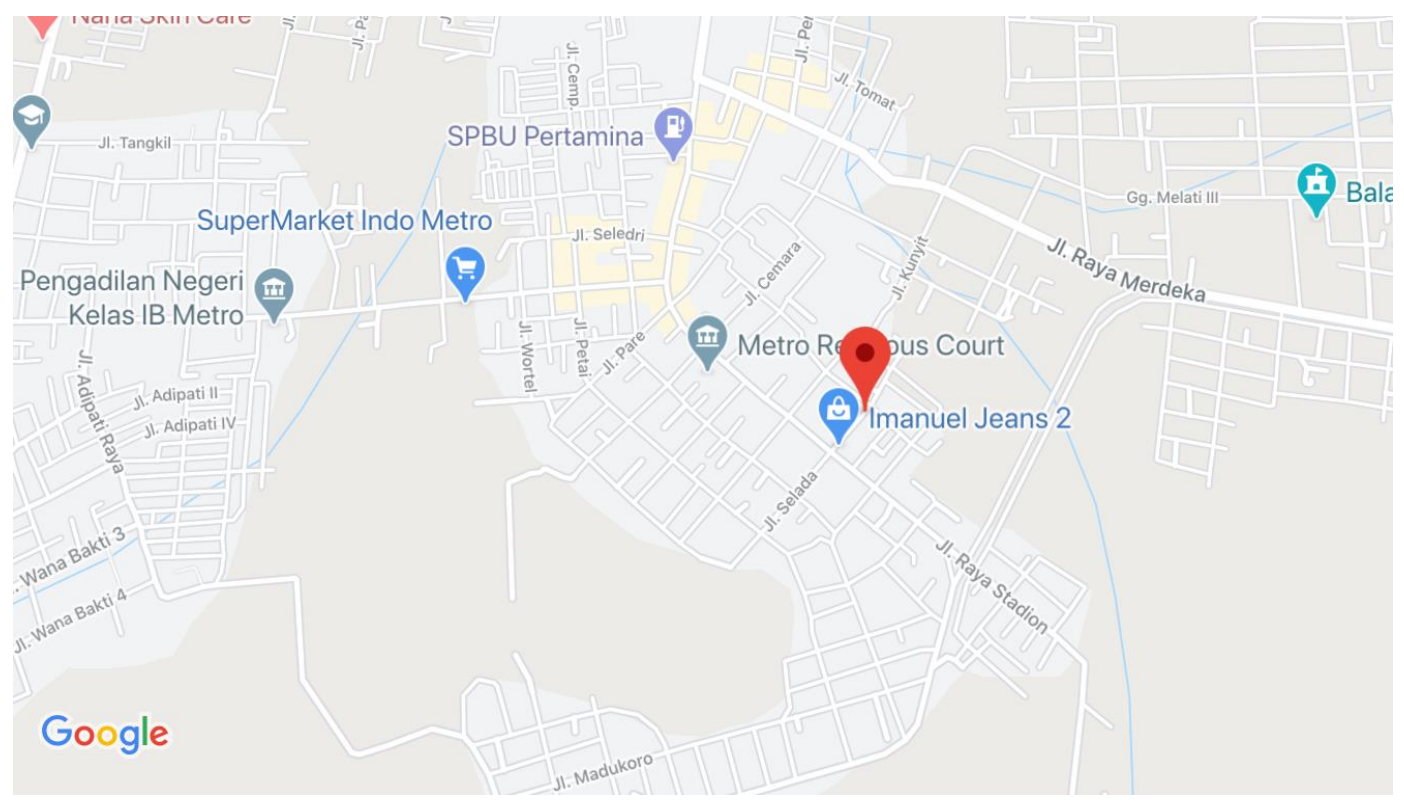

Gambar 2.1 Lokasi Klien di Kota Metro

\section{METODE}

\section{Tahap Persiapan}

Tahap persiapan dari kegiatan adalah pembuatan pre planning, persiapan tempat serta alat dan bahan lainnya disiapkan oleh peneliti. Kemudian peneliti menjelaskan maksud dan tujuan, menanyakan kesiapan klien, dan menjaga privasi klien, serta menjelaskan dan mendemonstrasikan prosedur kerja pemberian jus apel hijau untuk persiapan yang baik dan benar.

2. Tahap Pelaksanaan

Pada hari pertama melakukan pre test dengan mengkaji dan mengobservasi kolesterol pada klien dengan cara mengukur kadar kolesterol dengan menggunakan Easy Touch Cholesterol Kit. Kemudian, melaksanaan 
intervensi pemberian jus apel hijau. Jus apel hijau sebanyak $200 \mathrm{ml}$ diminum rutin satu kali sehari sesudah makan berbuka puasa selama 7 hari. Kemudian pada hari terakhir melakukan post test dengan mengkaji dan mengobservasi kolesterol pada klien dengan cara mengukur kadar kolesterol dengan menggunakan Easy Touch Cholesterol Kit.

\section{Evaluasi}

\section{a. Struktur}

Klien sebanyak 1 orang yaitu laki - laki. Setting tempat sudah sesuai dengan rencana yang dibuat serta alat dan bahan untuk mendemonstrasikan peberian jus apel hijau sudah tersedia dan sudah digunakan sebagaimana mestinya. Peran peneliti sudah sesuai dengan tugasnya, baik sebagai penanggung jawab, observator, fasilisator, dan dokumentasi. Penggunaan bahasa yang dipraktikkan sudah komunikatif dalam penyampaianya, klien dapat memahami apa yang sudah disampaikan dan dapat mempraktikkan kembali yang sudah didemonstrasikan.

\section{b. Proses}

Pemberian intervensi jus apel hijau dimulai pada hari Senin 27 April 2020 selama 7 hari.

\section{c. Hasil}

Hasil evaluasi pada klien diperoleh penurunan kadar kolesterol sesudah pemberian jus apel hijau.

\section{HASIL DAN PEMBAHASAN}

Tabel 4.1

Kadar Kolesterol Sebelum dan Sesudah Pemberian Jus Apel Hijau

\begin{tabular}{ccc}
\hline Pemberian Jus & Pretest & Posttest \\
\cline { 2 - 3 } Apel Hijau & $275 \mathrm{mg} / \mathrm{dl}$ & $239 \mathrm{mg} / \mathrm{dl}$ \\
\hline
\end{tabular}

Berdasarkan Tabel 4.1 menunjukkan hasil evaluasi pada klien, dimana klien mengalami penurunan kadar kolesterol setelah dilakukan pemberian jus apel hijau sebanyak $200 \mathrm{ml}$ selama 7 hari berturut-turut, diminum satu kali sehari sesudah makan berbuka puasa. Diperoleh kadar kolesterol sebelum diberikan jus apel hijau (pretest) yaitu $275 \mathrm{mg} / \mathrm{dl}$ dan kadar kolesterol setelah diberikan jus apel hijau (posttest) yaitu $239 \mathrm{mg} / \mathrm{dl}$, dimana mengalami penurunan sebanyak $36 \mathrm{mg} / \mathrm{dl}$.

Berdasarkan hasil penelitian Izzati, \& Salsabila (2018) tentang pengaruh jus apel hijau terhadap penurunan kolesterol, penelitian dilakukan dengan rancangan pre-eksperimental dengan pendekatan one group pretest posttest without control. Responden meminum jus apel hijau sebanyak $1 \times 200 \mathrm{ml}$ sehari selama 7 hari yang diberikan sesudah makan, dan pasien yang tidak sedang meminum obat penurun kolesterol. Hasil penelitian menunjukkan rata-rata kadar kolesterol sebelum diberikan jus apel hijau yaitu $270,50 \mathrm{mg} / \mathrm{dl}$ dan rata-rata kadar kolesterol setelah diberikan jus apel hijau yaitu 237,40 mg/dl, dimana mengalami penurunan sebanyak $33,1 \mathrm{mg} / \mathrm{dl}$. 
Tahun [JURNAL KREATIVITAS PENGABDIAN KEPADA MASYARAKAT (PKM), P-ISSN:

2021 2615-0921 E-ISSN: 2622-6030 VOLUME 4 NOMOR 5 OKTOBER 2021] HAL 1176-1183

Kolesterol adalah suatu zat berlemak yang diperlukan di dalam tubuh manusia untuk sintesa berbagai steroida seperti garam empedu, hormon steroid seperti progestin, hormon kelamin, dan sebagainya. Setiap hari tubuh mampu mensintesa sekitar 1 gram kolesterol. Di samping itu, kolesterol diperlukan untuk pembentukan jaringan otak dan sel syaraf. Tubuh dapat membuat kolesterol sendiri dari biosintesa asetat dalam limpa dan disebut kolesterol endogen. Selain itu, tubuh memperoleh kolesterol dari dua sumber yaitu dari makanan yang disebut kolesterol eksogen (Moehji, 2017).

Kolesterol yang meningkat dalam darah akan menimbulkan gejala. Gejala yang lazim meliputi nyeri kepala, pusing, lemas, kelelahan, gelisah, keringat dingin, mual, muntah, kaku kuduk, pandangan menjadi kabur, serta sakit dada yang bisa menyebar ke lengan, punggung, rahang (Nurarif, \& Kusuma, 2015). Cara penanganan untuk mengatasi kelebihan kolesterol dalam darah bisa dilakukan dengan cara farmakologi dan nonfarmakologi. Salah satu cara nonfarmakologi menurunkan kadar kolesterol dalam darah dengan mengonsumsi jus apel hijau.

Jus apel hijau sebagai solusi selain obat yang dapat dimanfaatkan untuk menurunkan kadar kolesterol berlebih pada tubuh dikarenakan kandungan pektin yang dikenal sebagai antikolesterol karena dapat mengikat asam empedu yang merupakan hasil akhir metabolisme kolesterol, makin banyak asam empedu yang berikatan dengan pektin dan terbuang keseluruh tubuh makin banyak kolesterol yang di metabolisme, sehingga pada akhirnya kolesterol menurun jumlahnya (Darsini, 2017). Rata-rata kadar pektin apel hijau varian Rome Beauty yaitu $0,57 \%$. Kandungan pektin yang berbeda pada setiap buahnya, bergantung pada perbedaan umur buah, keadaan iklim, tempat tumbuh, cara pemeliharaan dan pemanenan buah, dan penyimpanan buah pasca panen (Wahyuningtias, Susanto, \& Purwantiningrum, 2017).

Apel hijau juga memiliki flavonoid yang merupakan antioksidan potensial pencegah pembentukan radikal bebas. Senyawa ini mampu mencegah perlengketan sel darah dan kerusakan HDL. Flavonoid dapat mengencerkan kembali vikositas darah akibat penyumbatan pembuluh darah oleh kolesterol dan menjaga kadar normal HDL, sehingga dapat menurunkan kadar kolesterol yang tinggi (Darsini, 2017). Rata-rata kadar flavonoid (kuersetin) pada apel Rome Beauty yaitu $242.96 \mathrm{mg} / \mathrm{L}$. Kandungan flavonoid berbeda pada setiap buahnya, bergantung pada varietas, proses pengolahan, kondisi pertumbuhan, nutrisi tanaman, dan lama penyimpanan Hal ini menunjukkan bahwa apel lokal memiliki kadar zat gizi (khususnya flavonoid) yang lebih tinggi bila dibandingkan dengan apel impor meskipun harganya sedikit agak mahal (Cempaka, Santoso, \& Tanuwijaya, 2014).

Dari implementasi yang telah dilakukan dan evaluasi yang telah dibahas di atas dapat disimpulkan bahwa pemberian jus apel hijau efektif menurunkan kadar kolesterol, dan dari hasil evaluasi klien mengalami penurunan kadar kolesterol sebanyak $36 \mathrm{mg} / \mathrm{dl}$. Hal ini sesuai dengan teori bahwa buah apel hijau dapat membantu menurunkan kadar kolesterol karena kandungan flavonoid dan pektin. Rencana tindak lanjut yang dilakukan dengan menganjurkan klien untuk meminum jus apel hijau bila mengalami peningkatan kadar kolesterol, selanjutnya menganjurkan klien dan keluarga untuk memeriksakan diri ke pelayanan kesehatan terdekat bila sakit. 
Tahun [JURNAL KREATIVITAS PENGABDIAN KEPADA MASYARAKAT (PKM), P-ISSN:
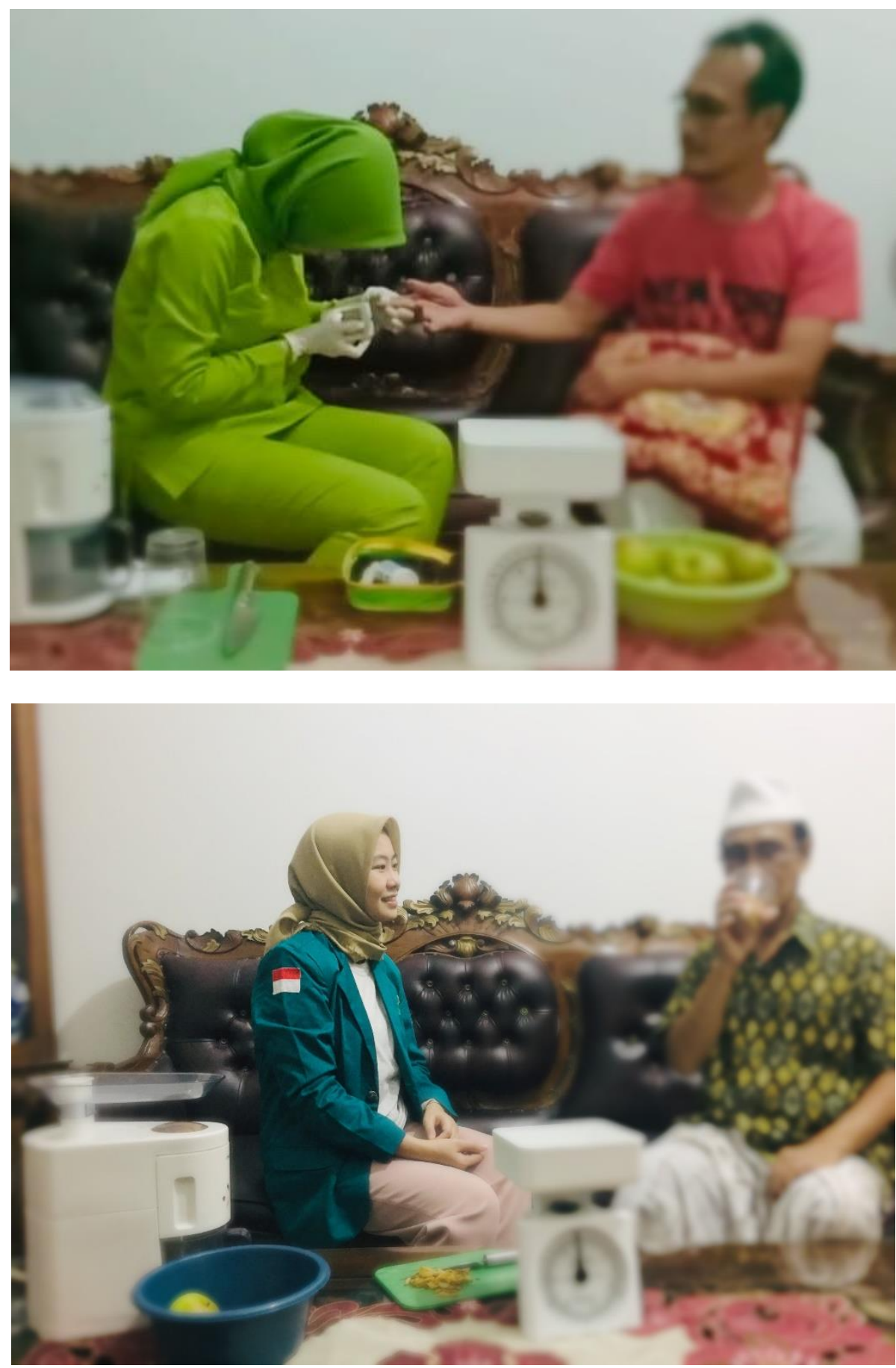


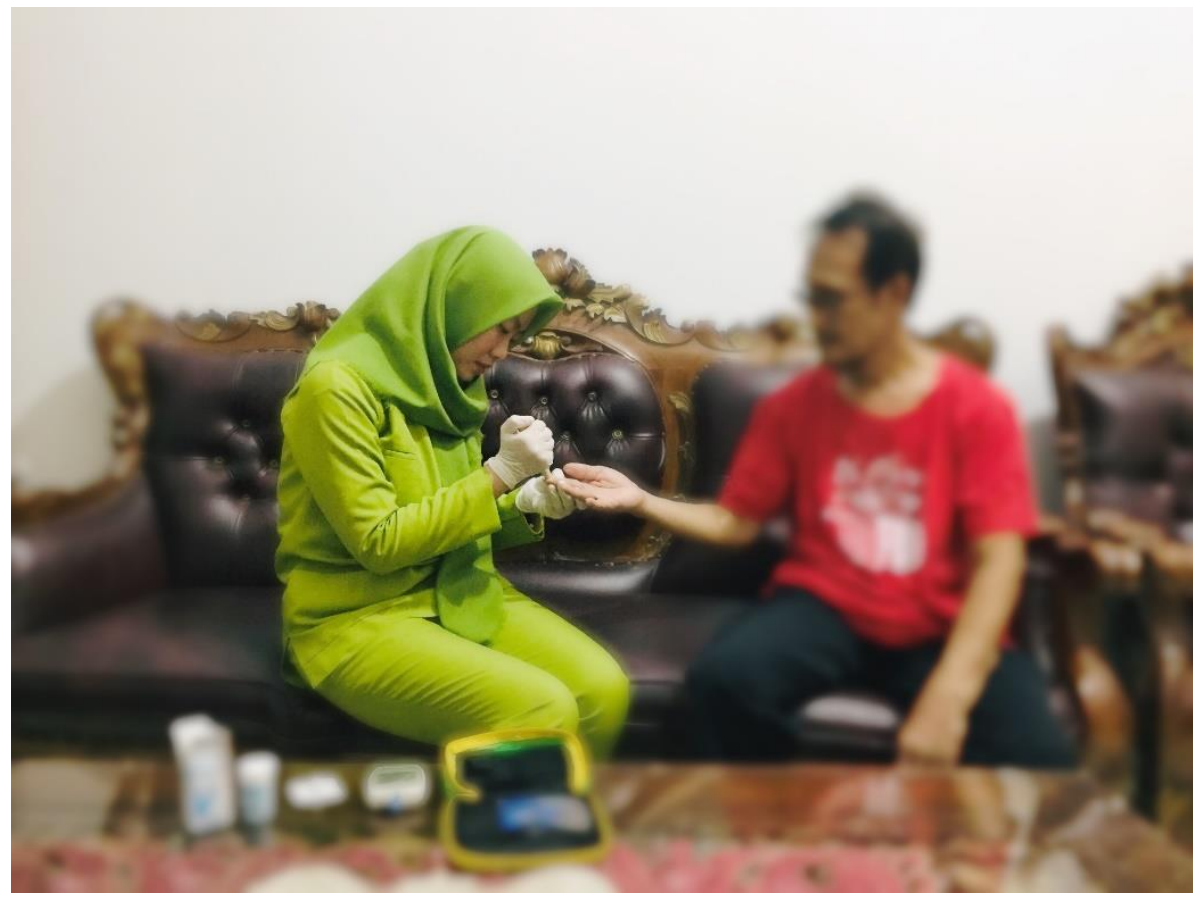

Gambar 4.1 Pelaksanaan Intervensi Pemberian Jus Apel Hijau

\section{KESIMPULAN}

Saat dilakukan pengkajian pada klien ditemukan data yang sesuai dengan tinjauan teori untuk masalah kolesterol pada klien. Berdasarkan data yang diperoleh, peneliti mendapatkan diagnosa keperawatan yang harus ditangani yang akan dijadikan suatu masalah. Pada intervensi keperawatan yang dilakukan pada klien yaitu sesuai dengan diagnosa keperawatan dan dilakukan pemberian jus apel hijau. Implementasi Keperawatan yang dilakukan berdasarkan pada intervensi yang telah direncanakan. Implementasi dengan pemberian jus apel hijau sebanyak $200 \mathrm{ml}$ selama 7 hari berturut-turut, diminum satu kali sehari sesudah makan berbuka puasa. Setelah dilakukan asuhan keperawatan dan pemberian jus apel hijau selama 7 hari, didapatkan hasil kadar kolesterol sebelum diberikan jus apel hijau (pretest) yaitu $275 \mathrm{mg} / \mathrm{dl}$ dan kadar kolesterol setelah diberikan jus apel hijau (posttest) yaitu $239 \mathrm{mg} / \mathrm{dl}$, dimana mengalami penurunan sebanyak $36 \mathrm{mg} / \mathrm{dl}$.

Pelaksanaan keperawatan ini memiliki kekurangan, salah satunya adalah intervensi yang dilakukan bertepatan dengan bulan puasa yang mengakibatkan terjadinya bias pada hasil pemeriksaan kadar kolesterol dikarenakan klien dalam keadaan puasa sehingga hasil pemeriksaan dapat terpengaruhi. Selain itu pelaksanaan keperawatan ini juga tidak menggunakan kelompok kontrol dan beberapa faktor seperti intake makanan, genetik, dan aktivitas dapat menyebabkan fluktuasi perubahan kadar kolesterol menjadi bias, serta kurangnya waktu yang cukup lama agar mendapatkan hasil yang lebih baik. 


\section{DAFTAR PUSTAKA}

Cempaka, A. R., Santoso, S., \& Tanuwijaya, L. K. (2014). Pengaruh metode pengolahan (Juicing dan Blending) terhadap kandungan quercetin berbagai varietas apel lokal dan impor (Malus domestica). Indonesian Journal of Human Nutrition, 1(1), 14-22.

Darsini, M. (2017). Pengaruh konsumsi jus apel terhadap penurunan kolesterol darah pada penderita hipertensi. Jurnal Keperawatan dan Kebidanan, 7(1).

Herningtyas, E. H., \& Ng, T. S. (2019). Prevalence and distribution of metabolic syndrome and its components among provinces and ethnic groups in Indonesia. BMC public health, 19(1), 377.

Izzati, W., \& Salsabila, R. M. V. (2018). Pengaruh Jus Apel Hijau Terhadap Penurunan Kolesterol Pada Penderita Hipertensi Di Nagari Kapalo Koto Wilayah Kerja Puskesmas Tigo Baleh Bukittinggi Tahun 2017. 'AFIYAH, 5(1).

Lestiani, L., Chandra, D. N., Laitinen, K., Ambarwati, F. D., Kuusisto, P., \& Lukito, W. (2018). Double-Blind Randomized Placebo Controlled Trial Demonstrating Serum Cholesterol Lowering Efficacy of a Smoothie Drink with Added Plant Stanol Esters in an Indonesian Population. Cholesterol, 2018.

Moehji, S. (2017). Dasar Dasar Ilmu Gizi 1. Jakarta: Pustaka Kemang.

Naue, S. H., Doda, V., \& Wungouw, H. (2016). Hubungan kadar kolesterol total dengan tekanan darah pada guru di SMP 1 \& 2 Eben Haezar dan SMA Eben Haezar Manado. eBiomedik, 4(2).

Nurarif, A. H., \& Kusuma, H. (2015). Aplikasi Asuhan Keperawatan Berdasarkan Diagnosa Medis \& NANDA NIC-NOC. Yogyakarta: MediAction.

Perkumpulan Endokrinologi Indonesia. (2015). Panduan pengelolaan dislipidemia di Indonesia. Jakarta: PB. PERKENI.

Sigit, F. S., Tahapary, D. L., Trompet, S., Sartono, E., van Dijk, K. W., Rosendaal, F. R., \& de Mutsert, R. (2020). The prevalence of metabolic syndrome and its association with body fat distribution in middle-aged individuals from Indonesia and the Netherlands: a cross-sectional analysis of two populationbased studies. Diabetology \& Metabolic Syndrome, 12(1), 1-11.

Wahyuningtias, C. T., Susanto, W. H., \& Purwantiningrum, I. (2017). Pengaruh Varietas Apel (Malus sylvestris Mill) Di Kota Batu Dan Konsentrasi Gula Terhadap Karakteristik Lempok Apel. Jurnal Pangan dan Agroindustri, 5(2). 